\title{
WOMEN'S HEALTH IS A TOOL FOR WORLD HAPPINESS
}

\author{
MOJDEH Pouryazdankhah - Phd student of the Department of International \\ and European Law, V. Karazin Kharkiv National University
}

УДК 341.215.4

DOI 10.32782/NP.2021.2.2

Bступ. У иій статті висвітлюеться еволючія жіночого руху за права жінок, концепція прав жінок на здоров'я та важливість прав жінок на здоров'я, підкреслюючи добровільне членство та прийняття ицих прав урядами та відуття морального та політичного обов'язку урядів як переваги.

Основна частина. Дана публікачія вивчає участь у договорах з прав людини. Гендерна нерівність завдає шкоди фбізичному та психічному здоров'ю мільйонів дівчат та жінок повсъому світу, а також хлопчиків та чоловіків, незважаючи на численні відчутні переваги, які вона дає чоловікам завдяки ресурсам, владі та контролю. Через кількість залучених людей та маситабність проблем, вжиття заходів для поліпшення гендерної рівності в галузі охорони здоров'я та забезпечення прав жінок на здоров'я $\epsilon$ одним із найбільи прямих та найпотужніших способів зменшити нерівність у здоров'і та забезпечити еббективне використання медичних ресурсів. Поглиблення та послідовне впровадження документів з прав людини може бути потужним механізмом мотиваціӥ та мобілізациї урядів, людей та особливо самих жінок.

Висновки. Гендерна нерівність икодить здоров'ю мільйонів дівчат та жінок по всъому світу. Це також може завдати шкоди здоровю чоловіків, незважаючи на численні відчутні вигоди, які мають чоловіки завдяки ресурсам, владі, авторитету та контролю. Ці переваги для чоловіків не приносять негативного впливу на їх власне емочійне та психологічне здоров'я, але часто перетворюються на ризиковану та нездорову поведінку та зменшують тривалість життя. Реалізація заходів для поліпшення гендерної рівності в охороні здоров'я та забезпечення прав жінок на здоров'я є одним із найбільш прямих та найпотужніших способів зменшити нерівність у здоров" $і$ в ичілому та забезпечити ебективне використання медичних ресурсів.

Ключові слова: право жінок на здоров'я, еволюиія прав жінок, рух за жіноче здоров'я, гендерна нерівність, гендерне право.

Introduction: (The relevance of research)

The first condition for having a healthy and dynamic society and health is the stability and strengthening of the family, and women guarantee the health and strengthening of the family. The family is the foundation and cornerstone of a social institution, and considering that educating the next generation is the responsibility of women. Dynamic is the result of the existence of healthy and aware women Which shows the importance of having health rights for women. Unfortunately, despite the international, international, regional organizations and groups active in the field of women's rights, we still see discrimination and lack of access to women's rights today, and it seems that this lack of access is due to ignorance and recognition of these rights by Women and the lack of government support in practice to facilitate women's access to health.

Analysis of recent research and publications, which initiated the solution of this problem and on which the author relies:

Many scientificpublications have paid great attention to the definition of the concept of "women's rights", gender equality, the effectiveness of 
mechanisms for the protection of human rights in general and women in particular. This scientific publication is based on the analysis of subsequent published works: "Issues in women's health and rights" January, Professor Emeritus of Obstetrics and Gynecology Assiut University Egypt; Women's Health and Human Rights, The Promotion and Protection of Women's Health through International Human Rights law 1994,Rebecca.Cook; Associate Professor (Research) and Director, International Human Rights Programme Faculty of Law, University of Toronto Toronto, Canada; Gender equality,work and health:A review of the Evidence Karen Messing, PhD,CINBIOSE, Université du Québec, Montréal, Canada and Piroska Östlin, PhD; KarolinskaInstitute, Stockholm, Sweden; Unequal, Unfair, Ineffective and Inefficient Gender Inequity in Health: Why it exists and how we can change it, Gita Sen, Piroska Östlin, Asha George, Anna Myagkykh is a Candidate of Law, Associate Professor, Coach, Human Rights Defender, Chairman of the NGO "Gender Club Dnipro" and head of the Gender Center of the State Higher Educational Institution "National Mining University" (Dnipro). Associate Professor of the Department of General Legal Disciplines of Dnipropetrovsk State University of Internal Affairs and Regional Coordinator of the Association of Women Lawyers "YurFem", Olena Uvarova, Associate Professor of Theory and Philosophy of Law, Ms. Olena Uvarova, Associate Professor of the Department of Theory of State and Law, Leading Specialist of the International Relations Department, Coordinator of Satellite Events of the Forum, Yaroslav the Wise National University of Law, Former National Adviser to the Council of Europe and Member of the Committee for the Protection of Women in Ukraine,Some aspects of women's right to health, including older women, to the works of Ukrainian writers in particular: Syroid T.,Fomina L., Havrylenko O.»

The purpose of this article: This article, with a general definition and expression of the concept of women's health rights, intends to point out the important role of governments in supporting and supporting this direction in order to achieve successful results for the future, after examining the evolution of women's health rights and existing problems.

Presenting the issue:

A quick look at the formation of women's movements for freedom and health rights re- veals that at different times, gender differences and gender discrimination have long been a major feature of ancient societies rooted in biological, genetic, environmental, economic, economic and social factors. Some groups of women face additional forms of discrimination based on their age, ethnicity, nationality, religion, health status, marital status, education, disability and socioeconomic status, among other grounds. In some parts of the world, women were practically seen as insignificant, and even today, women had low self-esteem and always apologized for their gender, and this lack of female value deprived them of health. Attaining equality between women and men and eliminating all forms of discrimination against women are fundamental human rights and United Nations values. Women around the world nevertheless regularly suffer violations of their human rights throughout their lives, and realizing women's human rights has not always been a priority. Achieving equality between women and men requires a comprehensive understanding of the ways in which women experience discrimination and are denied equality so as to develop appropriate strategies to eliminate such discrimination. All the disadvantages of women's access to their rights are referred to as injustice. [1- p 1]

These struggles began in New York in 1848 and reflected the equal rights of men and women (the suffrage movement). The women's movement grew steadily, encountering social and institutional barriers that limited women's rights (family responsibilities, lack of educational and economic opportunities). Did During the 1880s, women's movements failed to gain widespread support from women, which was the biggest obstacle to women's right to freedom. After the formation of the Congress in the United States, women entered the field and after many years won many seats. Gradually, the focus increased and women became known as the caretakers of the nation's greatest asset. One can argue that the Women's Health Movement started in the early 1900s with Margaret Sanger's fight for women's rights to birth control. [2]

The idea of equal social rights for women and men dates back to the era of the Enlightenment and the Great French Revolution of the 18th century and is associated with the approval of the liberal concept of "natural rights and freedoms" of 


\section{Теорія, історія держави і права, конституційне право}

man. For the first time in Europe, this concept was enshrined in the main document of the French Revolution, the Declaration of the Rights of Man and Citizen (1789). But after the publication of the Declaration, and then the Constitution of the new republic, they discovered that freedom and human rights did not apply to women: only men were classified as citizens who had the right to own property, elect and be elected. But the voice of the French revolutionaries was not heard, women's unions were banned, and then women were even banned from attending public events.[3]

In 1921, the first attempts were made to pass legislation to protect pregnancy and infancy (Prenatal health education for mothers and infants for social welfare), and after 1922, Congress passed a set of laws on child labor, Guaranteed women's employment, and their rights. Women played a prominent role as reformers and moderators in the early 19th century, after which women became known as a large nursing team during the Civil War and later as specialists. Women worked hard to enter political interests and their presence. It increased from one to 30, and women entered the judiciary as judges. [4]

During World War II, the significant presence of women in all fields, including the military, the presence of a large number of women as nurses on the battlefield was very significant and created many opportunities for women. [5]

In the modern era, the rights that can be used for women's health began with the enactment of the United Nations Charter in 1945, and then the Charter of the United Nations in 1948, paving the way for more international and regional instruments emphasizing the condemnation of gender discrimination. The network regulated rights related to the production and protection of health, and in the following years regional conventions discriminated against all because of my gender and promoted the need to protect rights related to health. [6- p1,2]

The women's rights movement and the women's sexual revolution in the 1960 s challenged many of the traditional concepts of motherhood and marriage. The women's social movement emerged in the late 1960s and early 1970s with a second wave of feminism focusing on improving women's health care and calling for equality in the home, workplace, and street (simultaneously in Europe and North America). [7]
The women's health movement, driven by the presence of women in the labor market, moved to improve working conditions, equal rights, and independence in decision-making on contraception, abortion, and sexual independence, and quickly entered other areas of women's health. [8]

Everyone sought to reform the law, change the mindset, and change the perception and role of women in society. The enthusiasm of women who experienced injustice, fought for their rights, and stepped up their tireless and active efforts led to the founding of the First International Women's Conference in 1975(At this meeting ,three objectives were identified in relation to equality, peace and development for the Decade: Full gender equality and the elimination of gender discrimination; The integration and full participation of women in development;An increased contribution by women towards strengthening world peace) and, long after, in 1995, the most progressive global program. To promote gender equality across the country. The Beijing Declaration, now a 25-year-old global declaration endorsed by 189 countries, aims to strengthen the rights and well-being of girls and women and affirms that: Women's rights are human rights. (The Beijing Declaration and Platform for Action were adopted at the Fourth World Conference on Women, held from 4 to 15 September 1995, by the representatives of 189 countries. The Platform reflects the new international commitment to achieving the goals of equality, development and peace for women throughout the world.The 12 critical areas of concern in the Platform for Action are as follows:Women and poverty,Education and training of women, Women and health, Violence against women, Women and armed conflict, Women and the economy, Women in power and decision-making, Institutional mechanisms for the advancement of women, Human rights of women, Women and the media, Women and the environment, The girl child.The Platform for Action sets out strategic objectives and explains the measures that should be adopted by Governments, the international community, non-governmental organizations and the private sector.) [9]

The feminist movements of majority women in both developed and developing countries are 
fraught with hierarchies and disregard for minority issues. They have not made space for the full empowerment of minority women within the movement. Women members of minority and indigenous groups in all regions of the world are struggling to be recognized and heard. They are hidden behind walls of prejudice, patriarchy, paternalism, traditions, culture and the boundaries of the home. They are easy and common targets of violence in the home, their communities and the larger society. Many strive to knit families together in communities fractured by conquest colonization slavery, imperial domination, and armed conflict. Poverty, ethnic prejudice and gender-based restrictions can weigh heavily on women and girls. And marginalized women bear the most severe negative consequences of the modern globalized economy .Roots of women's movements in protest against gender discrimination (inequality), lack of intellectual and economic independence and lack of health care, sports medicine, inequality and discrimination in employment, income and cessation of violence against women and prevention of domestic abuse and other violent crimes Women and the laws were to protect the family, children, control and study specific diseases of women. This shift in ideas about gender roles in the workplace and society created a political space for many women to flourish. The presence of a significant number of women in the social environment required that work be reconciled with family life and that a balance be struck between them. [10, p 7]

The predominant view today is still of women as reproductive beings, which unfortunately leads to neglect of women's health in other stages of life. Women's non-reproductive health is becoming important as a public health issue, mainly due to population ageing and changing lifestyles, but health systems, especially in low and middle-income countries, are not prepared to deal with the double burden of disease among women. [11,p 628]

Today, women have been transferred to a specific labor force, they may work at home or work outside the home, or they may be formally and informally involved in monetary, economic, agricultural, street and even sexual work, and contractual relationships. It is also different in terms of gender. Evidence suggests that as a group, women suffer more from competitive pressures and cost-saving strategies, which may be accompanied by a lack of limited security for education and career advancement, and inadequate social security coverage for aging pensions. The design of the organization and the standards of work, equipment, tools and work spaces are all based on gender and are usually designed for men. Women's access to jobs is restricted Women are still not allowed to work in many countries or have been excluded from certain types of work, low wages, all of which indicate gender discrimination.[12,P 2]

According to the World Health Organization, complete well-being is physical, mental, and social, and does not just mean the absence of disease and disability.

Rights related to the promotion and protection of women's health according to the WHO definition include the following:

- the right of women to be free from all forms of discrimination;

- rights relating to individual freedom and autonomy, including rights regarding survival, liberty and security, rights regarding

family and private life, and rights to information and education;

- rights to health care and the benefits of scientific progress;

- rights regarding women's empowerment, including the rights to

freedom of thought and assembly and the right to political participation. [13,p 4]

Women's primary health care is important for three reasons: first, the people who benefit directly from it, second, as mothers and family members, and third, as front-line health workers outside the home. Women have a more important role in determining the health of the community than men because not only their health responsibility but also most of the care for the health of the family is the responsibility of women and if their problems are ignored not only their own health but also the health of the family It becomes. [14]

Women make up almost half of the world's population, and their health has a direct impact on the health of their children, family, community and the environment around them. Given the differences between male and female organs, it is clear that diseases, drugs and medical devices used for treatment are also different, and the in- 


\section{Теорія, історія держави і права, конституційне право}

clusion of women in clinical trials has led to new advances that benefit women. [15]

Despite advances in eliminating social and health inequality between men and women over the past century, gender equality remains an unattainable goal, especially in developing countries, And many women and girls are still subjected to violence and other human rights abuses. When addressing women's lives, it is important to examine the basic socio-cultural, environmental, epidemiological and economic factors for health. Violence against women and girls is the most widespread human rights violation in the world today, and no country has yet achieved full equality, and women and girls experience several forms of discrimination throughout their lives. [16]

Here is a summary of 30 years of achievements in women's health: Increased lactation Although there are still differences between ethnic and racial groups, today these gaps have narrowed. Increasing the life expectancy of women means that women live longer due to preventive measures and new and better treatments for diseases, which is due to the increase in awareness and support of women by governments, which even many of these cares in some Countries are completely free for women,Improving mental health care for women, reducing breast cancer mortality, reducing smoking among women, reducing early pregnancy, screening and prevention of cervical and breast cancer, decrease in HIV/AIDS deaths in women and mother-to-child transmission of HIV decreased, Allocate funds to address violence against women, making birth control better, safer and more accessible for women, approval of emergency contraception and effort's to improve pregnant woman's health and outcomes, creation of woman health information resources, Free care for the elderly and minority women, the removal of dangerous medicines for women from the markets, government support for women's health care providers and claimants, further studies on the treatment of osteoporosis and certain types of cancer in women, Adopt laws to facilitate women's health care, including receiving health insurance and receiving health care costs, as well as increasing preventive care for women (prevention services). [17,p 5-33]

On the one hand, countries must address the unfinished business of sexual and reproductive health problems, malnutrition, HIV and other infectious diseases and gender-related issues, like gender-based violence and other forms of discrimination against women. On the other hand, countries must also tackle the emerging epidemic of chronic diseases. Governments are not focused explicitly on chronic diseases or allocating enough resources to deal with them. [18,p 628 -629]

\section{Result}

The XX-XXI centuries have become an era of gender equality - social equality of men and women, which implies the establishment of the foundations of gender balance and gender democracy. European countries are rapidly translating into practice the long-declared provisions that the empowerment of women, their participation on the basis of equality in all spheres of society, is one of the most important factors of economic and social development. For example, in many European countries, governments are headed by women, and equal representation of men and women in parliament has been achieved.[19]

Ensuring women's access to justice requires that women enjoy their right to equality before the law, that procedures are in place to guarantee non- discriminatory access to justice and that women have effective access to remedies when their rights have been violated. In recent decades, the international community has established clear legal norms regarding the prohibition of discrimination, the promotion of gender equality, and the promotion of women's rights and freedoms. (The principle of equality between men and women is fundamental to a modern understanding of human rights).[20,p 109]

The United Nations has a long history of addressing women's human rights and much progress has been made in securing women's rights across the world in recent decades. However, important gaps remain and women's realities are constantly changing, with new manifestations of discrimination against them regularly emerging. Some groups of women face additional forms of discrimination based on their age, ethnicity, nationality, religion, health status, marital status, education, disability and socioeconomic status, among other grounds. These intersecting forms of discrimination must be taken into account when developing measures and responses to combat discrimination against women.[21,p1] 
Governments should take all necessary measures to remove all obstacles, including selfidentification by region, individuals and level of awareness, and identify problems in each area and easily take steps to address them. Adequate government guarantee is the same as regulatory procedures and mechanisms to ensure women's access to appropriate and standard methods (respect for women's independence and the need for informed consent). Need to remove more barriers to access to contraception and provide sex education to guarantee sexual rights, need to ensure access to safe and legal abortion because limited abortion laws are kept in violation of the guidelines of international human rights treaties. Countries also ensure that women have full and equal access to sexual and reproductive rights (goods, services and health facilities) and that all adolescent girls and women have full access to sexual and reproductive health information. All training should be mandatory, comprehensive and age-appropriate. The characteristic of the participation of governments is that the tools they choose should lead to the promotion and protection of women's health, and should promote the dignity of women and their capacity to determine their own destiny.Elimination of laws and customs and prejudices that deprive women of their well-being and health, and the right of access to health through education and health services, must also be essential[22]

The positive performance of governments, the support of regional, international and global organizations to achieve these rights for women around the world, if realized, we will see a world full of peace, healthy children and almost a world free of mental and physical disabilities. The result is peace.

\section{Reference}

1.United Nations Human Rights, Women's Rights are Human rights, 2014, page 1, pdf. URL: www.ohchr.org/documents/events/whrd/ womenrightsarehr.pdf.

2.Assembling, Amplifying, and Ascending: Modern Trends Among Women in Congress, 1977-2020. URL :https://history.house.gov/ Exhibitions-and-Publications/WIC/HistoricalEssays/Assembling-Amplifying-Ascending/Introduction/
3.Pancho Arguelles, Suffrageism in the XIXXX centuries ,2007. URL: gender-route.org/ statya_na_glavnoj/sufrazhizm_v_xixxx_vekah 1 .

4. Theda skocpol, protecting soldiers and mothers the political origins of social policy in United State. Cambridge, Mass.: The Belknap Press, 1992). Pp. xxi, 714.). 494-522,URL:https://www.cambridge.org/core/ search?q=Theda+skocpol\&_csrf $=$ ZwWTuI0cCpPHhV2KhrDPNX4u7pm5ObMXf0Q

5. Assembling, Amplifying, and Ascending: Modern Trends Among Women in Congress, 1977-2020. URL :https:/history.house.gov/ Exhibitions-and-Publications/WIC/HistoricalEssays/Assembling-Amplifying-Ascending/Introduction/

6.WORLD HEALTH ORGANIZATION .women's health and Human rights:the promotion and protection of women's health through International Human rights law 1994. PDF page 1, 2 . Rebecca J.Cook ,URL: apps.who.int/iris/ handle/10665/39354

7.Assembling, Amplifying, and Ascending: Modern Trends Among Women in Congress, 1977-2020. URL :https:/history.house.gov/ Exhibitions-and-Publications/WIC/HistoricalEssays/Assembling-Amplifying-Ascending/Introduction/

8.Allison McGrath, origins of women's health movement,20 March 2019, URL: powertodecide.org/news/origins-womens-health-movement

9. United Nations, Outcomes on Gender and Equality, Commission on the Status of Women 49th session ,New York, 28 February-11 March 2005.URL:www.un.org/en/development//devagenda/gender.shtml

10. Joanna Hoare, State of the World's Minorities and Indigenous Peoples 2011, Violence against women in indigenous, minority and migrant groups, Violence against women in indigenous, minority and migrant groups,July 2011 , page 7, pdf.URL:www.researchgate.net/profile/Katalin-Halasz-3/publication/286924656_Violence_against_women in_indigenous_minority_and_migrant_groups/ links/566fffd $\overline{3} 08 \mathrm{ae} 486 \overline{9} 86 \mathrm{~b} 9676 \mathrm{a} / \mathrm{Violence}-$ against-women-in-indigenous-minority-and-migrant-groups.pdf?origin=publication_detail .

11.WORLD HEALTH ORGANIZATION , Anna Langer talks with Fiona Falak about a new women's health plan (outbreak of chronic dis- 
eases among women), 2013, page 628.pdf. URL: dx.doi.org/10.2471/BLT.13.030913.

12. WORLD HEALTH ORGANIZATION. Gender Equality Work and Health. 2006, p 2, https://www.who.int/gender/documents/Genderworkhealth.pdf.

13.WORLD HEALTH ORGANIZATION .women's health and Human rights:the promotion and protection of women's health through International Human rights law 1994. Rebecca J.Cook ,URL: apps.who.int/iris/handle/10665/39354.

14.Jayita Poduval and Murali Poduval, Working Mothers: How Much Working, How Much Mothers, And Where Is The Womanhood?,2009,Jan-Dec. URL: www.ncbi. nlm.nih.gov/pmc/articles/PMC3151456/

15.Erin M Falconer et al. Brain Res. Sex different at cellular level:"cell have a sex",2012,Starface,E,et.al (214):49-65. URL:pubmed.ncbi.nlm.nih.gov/12763590

16.Nils Muižnieks, Protect women's sexual and reproductive health and rights, ,21 July 2016,URL:www.coe.int/en/web/commissioner/ blog/-/asset_publisher/xZ32OPEoxOkq/content/ protect-women-s-sexual-and-reproductivehealth-and-rights?_101_INSTANCE_xZ32OPEoxOkq_languageI $\bar{d}=e_{-}$GB.

17.OWH,Women'shealth.gov,Nancy Lee,c oordinating committee on women's health. 30 Achievement in women's health in 30 years(1984-2014), 2014. Pdf, page 5-33, URL: www.womenshealth.gov/30-achievements/nancy-lee,

18.WORLD HEALTH ORGANIZATION. Analanger, Thenewwomen's healthagenda,world health organization.from bull world health organ ,page 628-629, sep ,2013, URL:www.who. int/bulletin/volumes/91/9/13-030913/en.

19. Soroka Yana Yuriyivna, Development of gender legislation, URL: minjust.gov.ua/m/ str_11921.

20. United Nations Human Rights, Women's Rights are Human rights, 2014, page 109, pdf. URL: www.ohchr.org/documents/events/whrd/ womenrightsarehr.pdf.

21. Women's Rights are Human Rights, United Nations human rights office of the high commissioner,NATIONS PUBLICATION SALES NO. E.14.XIV.5,ISBN 978-92-1-154206-6,E-ISBN９78-92-1-056789-
Introduction. This article highlights the evolution of the women's movement for women's rights, the concept of women's health rights and the importance of women's health rights, emphasizing voluntary membership and the adoption of these rights by governments and the sense of moral and political duty of governments as advantages.

Main part. This publication examines participation in human rights treaties. Gender inequality harms the physical and mental health of millions of girls and women around the world, as well as boys and men, despite the many tangible benefits it gives men through resources, power and control. Due to the number of people involved and the scale of the problems, taking measures to improve gender equality in health care and women's rights to health is one of the most direct and powerful ways to reduce health inequalities and ensure the efficient use of health resources. Deepening and consistent implementation of human rights instruments can be a powerful mechanism to motivate governments, people and especially women themselves.

Conclusions. Gender inequality is detrimental to the health of millions of girls and women around the world. It can also be detrimental to men's health, despite the many tangible benefits that men have from resources, power, and authority and control. These benefits for men do not have a negative impact on their own emotional and psychological health, but often turn into risky and unhealthy behavior and reduce life expectancy. Implementing measures to improve gender equality in health care and ensuring health benefits is one of the most direct and powerful ways to reduce overall health inequalities and ensure the efficient use of health resources.

Key words: women's right to health, evolution of women's rights, women's health movement, gender inequality, gender law.

3,New York and Geneva, 2014, page 1, URL:www.ohchr.org/documents/events/whrd/ womenrightsarehr.pdf

22. Nils Muižnieks, Protect women's sexual and reproductive health and rights, July 2016,URL:www.coe.int/en/web/portal/news2016/-/asset_publisher/StEVosr24HJ2/content/ protect-women-s-sexual-and-reproductivehealth-and-rights 